\title{
The Early History of Research on Ornamental Plants at the U.S. Department of Agriculture from 1862 to 1940
}

\author{
R.J. Griesbach \\ Floral and Nursery Plant Research Unit, U.S. National Arboretum, U.S. Department of Agriculture, Agricultural \\ Research Service, Beltsville Agricultural Research Center-West, Beltsville, MD 20705-2350 \\ S.M. Berberich \\ National Visitor's Center, U.S. Department of Agriculture, Agricultural Research Service, Beltsville Agricultural \\ Research Center, Beltsville, MD 20705-2350
}

The first researchers (1862-1940) of ornamental plants for the U.S. Dept. of Agriculture (USDA) were as well-trained and knowledgeable as any horticulturists of their day. Early USDA horticultural researchers published little of their experiments and innovations; however, their legacy of information and new cultivars was indeed rich (Emsweller et al., 1937).

By the mid-19th century, the need to lay foundations for farm industries - by organizing agricultural research, including horticulture-had become obvious to the federal government. In 1862, during the Civil War, President Abraham Lincoln signed into law a federal agriculture department, with horticulture as a prominent part of the blueprint.

From its inception, the USDA has been actively involved in research on ornamental plants. In the first USDA Annual Report, two chapters were devoted to ornamental plants (Hall, 1863). One chapter was entitled "House Plants" and the other "Flowers in the Garden." The official mission of the USDA was "to acquire and diffuse among the people of the United States useful information on subjects connected with agriculture... and to procure, propagate and distribute among the people new and valuable seeds and plants."

When established in 1862, the department had only two divisions: Farm and Garden. George Reid was responsible for "farm" or agricultural research; while William Saunders was responsible for "garden" or horticultural research. Saunders, with more than 300 publications, was a notable exception to the rule for early USDA researchers. Work he initiated improved agriculture throughout the nation, and, with other USDA pioneers, such as David Fairchild, he developed the foundation for the comprehensive network of germplasm introduction, evaluation, collection, and research that is in place today.

\section{Research mission}

Saunders set the mission for horticulture research with nine goals (Saunders, 1897): “1) To procure seeds, cuttings, bulbs, and plants from foreign and domestic sources and test their merits in various local conditions; 2) to

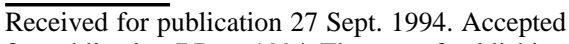
for publication 7 Dec. 1994. The cost of publishing this paper was defrayed in part by the payment of page charges. Under postal regulations, this paper therefore must be hereby marked advertisement solely to indicate this fact. hybridize or culture plants of superior traits; 3 ) to test products in varied culture, and the effects of pruning and other manipulation on trees and fruits; 4) to investigate disease and insect pests; 5) to thoroughly test all seed samples and other plant propagation materials; 6 ) to cultivate hedge plants and show their usefulness; 7) to collect and cultivate the best fruit trees and plants; 8) to plant a collection of choice shrubs, gardens, and landscape scenery; and 9) to erect greenhouses for display of exotic plants and teach the best and most economical constructing, heating, and managing of such buildings."

As time passed, however, it became evident that not all of the intended goals could be accomplished with only two USDA research divisions. Therefore, the Botany Division was established in 1869; the Pomology and Vegetable divisions in 1887; and the Foreign Seed and Plant Introduction Division in 1898. The first building for the Dept. of Agriculture was constructed on the Mall in Washington, D.C., in 1867.

Saunders managed the landscape around the building as a research and educational tool. Today, botany students take such teaching gardens for granted; but, in his day, Saunders' efforts represented a novel approach. In fact, the idea was awarded a gold medal at the 1889 Paris Exposition. In 1871, a conservatory for maintaining tropical economic plants (Fig. 1) was constructed next to the building, with a "view to the propagation and distribution of such as might be deemed worthy of trait in suitable climates of the country" (Saunders, 1897).

One of Saunders' earliest successful introductions was the navel orange (Citris sinensis Osbeck). In 1871, several orange trees that produced seedless fruit were imported from
Bahia, Brazil. In 1873, Saunders sent two budded 'Washington Navel' trees to Eliza Tibbits of Riverside, Calif. In 1879, she entered one in a citrus exhibition, where its commercial importance was recognized. One of those trees is fenced off, as sort of a "museum piece," in downtown Riverside today. Saunders also introduced hardy apples (Malus Mill) from Russia at about the same time.

Saunders' most historic accomplishments were not new crop introductions. He planned the Civil War Cemetery at Gettysburg; selected the site and designed the Lincoln Memorial in Washington, D.C.; and was the principal organizer of the Patrons of Husbandry, or the Grange, which was a strong influence in improving U.S. agriculture.

In the early days, before 1900, much of the research was conducted at the scientist's own expense. In designing the cemetery at Gettysburg, Saunders received no compensation other than his regular salary from the government. He had to pay for his own travel as well as any other expenses not directly connected with its construction (Galloway, 1900).

\section{Growth in research programs}

When, in 1900, significant funds became available, the USDA established its Bureau of Plant Industry and selected B.T. Galloway as its chief. The bureau had seven divisions: Vegetable, Pomology, Botany, Foreign Seed and Plant Introduction, Grass and Forage, Horticulture, and Experimental Greenhouse and Gardens (EGG). Staff within the Horticulture, Foreign Seed and Plant Introduction, and EGG divisions were directly involved in research on ornamental plants.

The Horticulture Division was led by L.C.

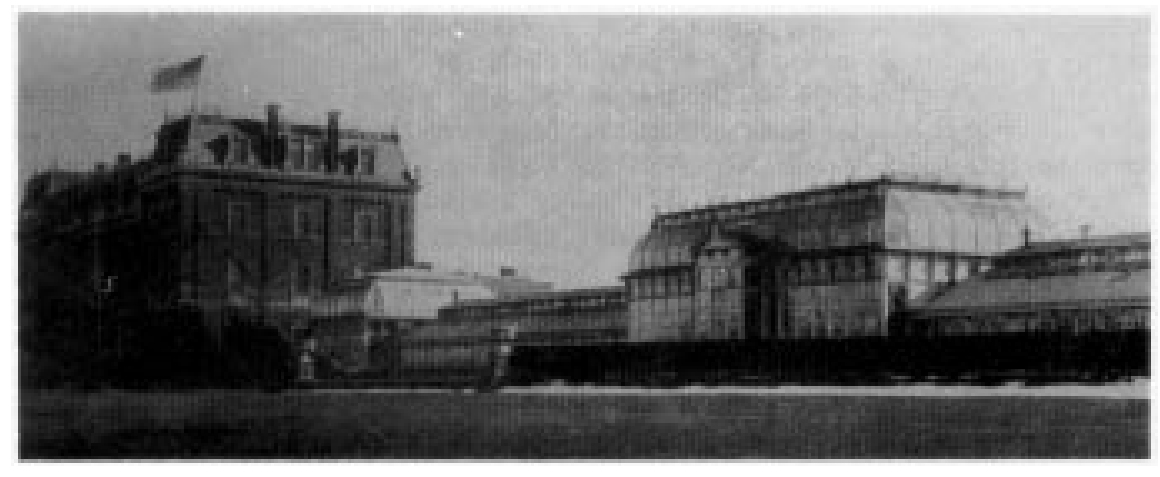

Fig. 1. The conservatory of the U.S. Dept. of Agriculture on the Mall in Washington, D.C. (Mar. 1909). 
Corbett, who was also responsible for the newly established Experiment Station in Arlington, Va., where the Pentagon is now located. E.M. Byrnes headed the EGG Division following Saunders' death in 1900. David Fairchild headed the Foreign Seed and Plant Introduction Division.

Researchers within the Vegetable Division studied ornamental plant diseases. Erwin F. Smith investigated the causes and control of bulb rots (Smith, 1901). Meanwhile, Albert F. Woods developed control measures for insect pests (Woods, 1900).

Greenhouses were erected in 1902 on the Mall in Washington, D.C., for the EGG Division and in 1910 on the Arlington Farm Experiment Station in Virginia for the Horticulture Division. In the first years of ornamental research at the USDA, considerable effort went into evaluating species for winter hardiness, heat tolerance, and general ability to grow under conditions in the United States. In 1903, the EGG Division propagated for evaluation 98,078 plants of 69 species. In the gardens around the USDA building, the division planted 34,097 bedding plants of 69 species! Besides conducting research on plants, the EGG Division was also responsible for conducting research on greenhouse design (Galloway, 1899).

From 1900 to 1935 , extensive research was conducted on bulbs, roses (Rosa L.), carnations (Dianthus L.), dahlia (Dahlia Cav.), chrysanthemums (Dendranthema grandiflora Tzvelev.), and azaleas (Rhododendron L.). Key researchers were A.J. Pieters, David Griffith, J.B.S. Norton, W. Stuart, Walter van Fleet, George W. Oliver, E.M. Byrnes, J. Wise Byrnes, Benjamin Y. Morrison, J. Marion Shull, Freeman Weiss, and Furman L. Mulford. Each made many important discoveries and released trend-setting cultivars.

For example, Oliver developed new summer-flowering dahlias by crossing an unidentified summer-flowering species from Mexico with commercially available fall-flowering cultivars. In the early $1900 \mathrm{~s}$, most of the cut flowers were raised in fields, not in greenhouses, as many are today. Dahlias-a popular cut flower-required a long growing period. Before Oliver, they did not flower until the end of summer or beginning of fall, thus greatly restricting the market. In 1907, he released one of his most popular cultivars, 'Cosmos'. Other breeders subsequently identified other summer-flowering species and included them in their breeding programs. The ancestry of many of our modern garden dahlias can be traced to USDA hybrids. Oliver also was involved in developing better methods to germinate lily (LiliumL.) seeds (Oliver, 1903).

For carnations, inheritance of flower doubleness was another unknown at the turn of the century. It was not possible to systematically and routinely produce seedlings with double flowers. That began to change when Norton became the first to apply genetics principles to carnation breeding. At that time, plant scientists were rediscovering Mendel's Genetic Principles, which had been published 35 years earlier (Spillman, 1909; see also
USDA Miscellaneous Publication 164, 1934). The principles led Norton to the genetics of double-flowered carnations (Norton, 1905). Stuart, in collaboration with Norton, developed the first practical method for producing large numbers of double-flowered seedlings (Stuart, 1912). After Stuart retired, E.M. Brynes continued the carnation breeding project. The USDA released more than a dozen cultivars between 1910 and 1935. 'Riggoletto' was one of the most popular of the USDA carnations.

In addition to breeding, A.F. Woods released valuable information on the identification and control of various carnation pests and diseases (Woods, 1900). He discovered that aphids were responsible for transmitting an important disease now known to be caused by a virus.

The USDA also was instrumental in developing the greenhouse carnation. In the 1901 USDA annual report (Galloway, 1901), it was stated, "The plan of never growing the carnation outdoors is, we believe, much more satisfactory for the commercial growers than the outdoor plan usually followed. While this scheme requires the use of a house throughout the entire year, it nevertheless overcomes the great shock to which the plants are subjected in lifting them in the autumn, and results in a very much larger and earlier yield of flowers."

\section{Research on woody perennials}

Another USDA innovation, by Walter van Fleet, were "dooryard" roses (dooryard was a term used in the early 1900 s for what we now call the backyard). van Fleet was a physician by training but a very successful breeder of strawberry (Fragaria L.), rose (Rosa L.), corn (Zea mays L.), tomato (Lycopersicon esculentum Mill.), pepper (Capsicum annum L.), canna (Canna L.), gladiolus (Gladiolus L.), geranium (Pelargonium L. Her.), and honeysuckle (Diervilla Adans.). Because of van Fleet's success in breeding roses (e.g., 'American Pillar', 'Daybreak', and 'Silver Moon'), Fairchild convinced him to work at the USDA on a project designed to create the ideal American garden rose. The project led to the development of dooryard roses, now called "shrub" roses. They are large, shrub-like plants with disease and pest resistances and heat and cold tolerances. They have beautiful foliage, fruit, and flowers. Their flowers are less formal and not as refined as florist roses. van Fleet created this new type of rose by crossing four wild species-Rosa wichuraiana Crep., moyesii Hemsl. \& Wils., rugosa Thunb., and setigera Michx.-with highly developed hybrid tea roses from Europe and florist cultivars (van Fleet, 1916).

van Fleet decided early in his USDA career that a large-scale rose breeding program could not be accomplished on the Mall in Washington, D.C. Therefore, he bought a house and property near the train station at Bell Station, Md. He worked at home, only commuting to his "office" in Washington on Fridays. His home eventually became the National Plant Germplasm Quarantine Laboratory at Glenn Dale, Md.
Twenty-nine rose cultivars were introduced by van Fleet between 1889 and 1926. In 1921, 'Mary Wallace'-named after Secretary of Agriculture Henry C. Wallace's daughterwas released. Seven years later, it was voted the number one rose in the American Rose Society's popularity poll. In addition, it won numerous medals and awards. The dooryard roses were so popular that the American Rose Society entered into a licensing agreement with the USDA for their propagation and distribution (McFarland, 1924). One of van Fleet's cultivars, 'Sarah van Fleet', is still sold today.

McFarland (1924), editor of the American Rose Annual, commented, "Nowhere else in the world is there going on such a systematic and orderly attempt to obtain a better rose variety for a specific purpose... He is probably the greatest plant-breeder America has yet known."

At the same time, a large-scale rose evaluation trial was conducted under Mulford's direction at the Arlington Farm Experiment Station in Virginia. The trial produced considerable data on many traits (e.g., plant height and growth habit, foliage type, disease resistance, length of blooming season, and number of flowers). In 1919, Mulford published a report of the performance of 430 rose cultivars over 5 years (Mulford, 1919). This trial was one of the first evaluations on cultivar performance of an ornamental plant over several seasons.

In addition, Mulford worked with L.B. Scott and Guy E. Yerkes of the Fruit Division to test and compare the performance of rose understocks (Yerkes, 1927). Mulford also collaborated with Anna E. Jenkins of the Vegetable Division on identifying and controlling diseases. C.A. Weigel and Floyd L. Smith of the Bureau of Entomology collaborated with Mulford on insect pests. van Fleet used their information in his breeding program, which produced USDA rose cultivars that were resistant to one or more pests and diseases.

When van Fleet died, B.Y. Morrison was placed in charge of the rose breeding program (Corbett, 1924). He gradually phased out the program by selecting and releasing the last cultivars. Morrison then started his own research project in 1929 on azalea improvement.

R.K. Beattie collected many Japanese Kurume and Satsuki azalea hybrids in 1928, and the Foreign Plant Introduction Division at the station tested them. Many of the Japanese cultivars had improved flowers, but they were not hardy. Morrison (1953) wanted to "create races of azaleas that should be hardy at Washington, D.C. and that should have flowers as large as those borne by the varieties of Indian azaleas which were the great ornament of southern gardens." At Glenn Dale, Morrison crossed the tender Kurume, Satsuki, and Indian cultivars with the hardy Rhododendron kaempferi Planch and $R$. poukhanense Lev. In 1939 , the first selections from these crosses were released as Glenn Dale cultivars. Out of the original 75,000 seedlings, only 454 cultivars were introduced (Morrison, 1953). The Glenn Dale azaleas are valuable for their large flowers; dense growth habit, which does not 
need pruning; heat and cold tolerance; and evergreen foliage. Many of them are still popular today, such as 'Martha Hitchcock', named after the wife of the renowned grass taxonomist, James Hitchcock.

\section{Research on chrysanthemum}

Before 1850, chrysanthemums were grown only as winter-flowering, southern garden plants. Most were imported from Japan. The USDA helped develop the first greenhouse cultivars in the late 1880 s, then in the early 1900s, it developed hardier garden types with earlier fall flowering.

In the early 1920s, Mulford collaborated with Harry A. Allard, a codiscover of photoperiodism. USDA scientists Wightman W. Garner and Allard discovered in 1918 that changes in the length of light period controlled flower development. They named the response "photoperiodism" (Garner and Allard, 1920). Garner and Allard investigated the photoperiodic response of many ornamental plants-freesia (Freesia Klatt), dahlia, cosmos (Cosmos Cav.), violets (Viola L.), and chrysanthemum. In light studies using chrysanthemum, Allard and Mulford tested and determined the photoperiodic response of many cultivars. Their collaboration resulted in the release of the first summer-flowering garden chrysanthemums. More than 400 USDA cultivars were introduced. The USDA also had an official chrysanthemum trial garden, which was under the direction of A.C. Hildreth, at its Cheyenne Horticultural Field Station in Wyoming. In 1938, more than 500 cultivars were being evaluated.

While Mulford and Hildreth were concentrating on garden chrysanthemums, Byrnes was involved in acquiring, testing, and releasing another kind - the florist chrysanthemum. Beginning in 1902, a formal chrysanthemum show was held in the USDA greenhouse on the Mall. The largest show was held in 1938, with more than 60,000 people in attendance (Ferrall, 1938). More than 1000 plants of 218 largeflowered Japanese cultivars, more than 600 plants of 346 garden cultivars, and several hundred plants of 11 Japanese cascade cultivars were exhibited. A highlight of the show was a display featuring the new USDA cultivar Mrs. Roosevelt, named after the President's wife. Franklin and Eleanor Roosevelt were actively involved in hosting many of these shows.

\section{Research on bulb crops}

Research at the USDA helped establish the bulb industries. The research project on bulbs, though, started as a congressman's perk. In the Congressional Seed Distribution Program, seeds, bulbs, and plants were propagated and given to senators and congressmen for distribution to their constituents. Unlike studies previously described here, which were conducted on the East Coast, this research was done on a 25-ha farm in Bellingham, Wash. The project supplied 110,000 tulip (Tulipa L.) bulbs and 100,000 to 150,000 daffodil (Nar-

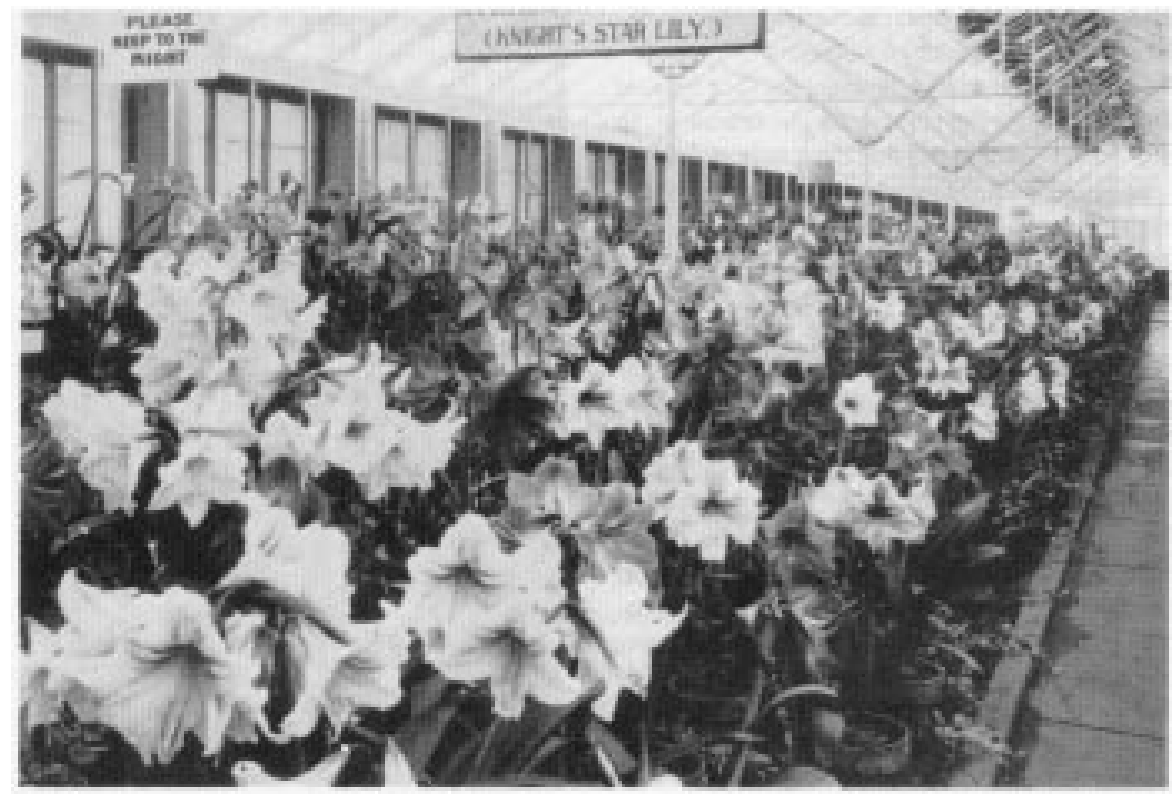

Fig. 2. View of the 1936 amaryllis show held in the U.S. Dept. of Agriculture greenhouses on the Mall in Washington, D.C.

cissus L.) bulbs per year to the Congressional Seed Distribution program!

The scientists on this project developed the first procedure for mechanically planting, using horse-pulled planters, and harvesting bulbs. Griffith (1932) said in an interview, "The use of the horse saves one-half of man energy, is more efficient, and entails less injury to the stocks than did the old bed method of culture imported from Holland. It also has the advantage of better enabling the grower to gauge the depth of planting and disposing of crop residue."

The problem at the turn of the century was that many bulbs were sold as sexually propagated seed lines and were not uniform. Griffith, however, stressed the need for vegetative propagation instead of seed propagation. $\mathrm{He}$ developed large-scale, commercially successful methods for vegetatively propagating lily (Lilium L.) (Griffith, 1920), daffodil (Griffith, 1930a), tulip (Griffith, 1922), hyacinth (Hyacinthus L.) (Griffith, 1930b), and iris (Iris L.) (Griffith, 1928) bulbs. E.F. Smith identified many of the bacterial diseases affecting bulbs. Freeman Weiss continued this work in more detail and developed methods for disease control during forcing (Weiss, 1930).

The results of the bulb research were not limited to new culture, propagation and production techniques, but included the release of several cultivars. A group of 11 cultivars involving Lilium humboldtii Roezl \& Leicht, $L$. parryii Wats, and $L$. pardalinum Kellogg were released by the USDA in the late 1920 s and early 1930s as Bellingham Hybrids (Griffith, 1933). 'Shuksan', released in 1931, was listed in a 1944 catalog (Sandyloam Garden Lilies, North Springfield, Vt.) as "one of the finest hybrids of American origin." This cultivar is still commercially available.

The USDA's greenhouses on the Mall in Washington, D.C., (Fig. 1) were sometimes used for spectacular flower shows. From 1912 to 1939 , an annual amaryllis (Hippeastrum Herb.) show featured current Dutch cultivars, as well as recent USDA releases (Fig. 2). One of the largest amaryllis shows was held in 1938, when 37,391 people visited the exhibit (Bahrt, 1938) and more than 1250 bulbs were in flower. The amaryllis breeding project started in 1909 when 12 cultivars were imported from England. One of the project's major achievements was the development of a pure-white strain obtained through selective breeding of "striped" types that showed less and less color.

\section{Program expansion}

Between 1930 and 1940 there was a steady expansion of organizational structure and buildings. In 1930, a new Horticultural Crops and Diseases Division was established. The new division combined the previous Horticulture, Vegetable Diseases, Crop Physiology, Fruit Diseases, Plant Pathology, and Plant Physiology divisions into one unit. The EGG Division and Arlington Farm, however, were not part of the new division.

During the 1930s, USDA gradually acquired land in Washington, D.C., for the National Arboretum, which today is an important part of the USDA. Morrison, after his service at Glenn Dale, was appointed the arboretum's first director. However, research at the arboretum did not start until after World War II. Before that, it had been used mostly as a federal repository for collected plants and seedlings from the various USDA breeding programs.

In 1935, the Bankhead Jones Act was passed by Congress. This act changed the mission of the research at the USDA from a practical to a more basic approach. Significant new funds, a $10 \%$ increase for many divisions, were made available to "conduct research into laws and principles underlying basic problems of Agriculture in its broadest aspects" (Ling, 1935).

The previously mentioned photoperiodism project was one of the first to benefit from the 


\section{Feature}

change in mission. Botanist Harry A. Borthwick and plant physiologist Marion W. Parker were hired to determine the mechanism responsible for the photoperiodic response. In 1938 , they discovered that even a short flash of low-intensity light during the night prevented flowering of certain plants that need a long uninterrupted dark period (Parker and Borthwick, 1940). This was a significantly less expensive procedure than what was currently being used by the industry - extending the daylength through continuous, high-irradiance lighting.

At the same time, construction was started on the U.S. Horticulture Station at Beltsville, Md. The station officially opened in 1939, with J.H. Beattie as its director. There were three buildings with greenhouses on $\approx 280$ ha. More than one-third of the greenhouses were used for research on ornamental plants. For the Horticulture Division, this was the first time that clerical, administrative, fiscal, greenhouse, field, and laboratory work were located at the same site.

In 1941, the 31 greenhouses of the Gardens and Grounds Division on the Mall were taken down and the plants were moved to the Beltsville station. More than 85 truckloads of 7000 chrysanthemum plants were moved along with 30,000 other plants! Research conducted by the EGG Division was transferred to the Horticulture Division under Ornamental Plant Crops and Diseases Investigations.

In 1935, Griffith was selected to lead the newly formed Ornamental Plant Crops and Diseases Investigations within the Horticulture Division. After Griffith's death that same year, geneticist Samuel L. Emsweller was placed in charge of the group (Fig. 3), which included D. Victor Lumsden, Neil W. Stuart, and Hamilton P. Traub (physiology); Philip Brierley, Lucia McCulloch, Louis P. McCann, WilliamD. McClellan, and Frank P. McWhorter (pathology); and Robert L. Pyror (genetics).

Lilies-their culture, production, and propagation - were the main focus of the newly formed Ornamental Plant Crops and Diseases Investigations. Why did lilies deserve so much emphasis? There were several reasons. 1) Easter lilies were one of the top five U.S. ornamental crops in value. 2) Almost all U.S. bulbs were imported, mainly from Japan; in 1937, this amounted to 36 million bulbs. There was essentially no major U.S. production. 3) During the 1930s viral diseases greatly decreased the quality of the imported bulbs. 4) Limited scientific information was available on culturing, producing, and forcing this crop. 5) During the Depression, considerable government funds were directed to projects that increased employment.

The goal of the large-scale lily project was to identify and solve problems associated with the growth and development of a self-reliant, U.S. lily industry. Stuart studied the physiology of dormancy and forcing. He developed methods for bulb storage that resulted in a high-quality flowering plant in the shortest time possible (Stuart, 1943). Stuart's experiments demonstrated for the first time that storage conditions had a dramatic effect on the

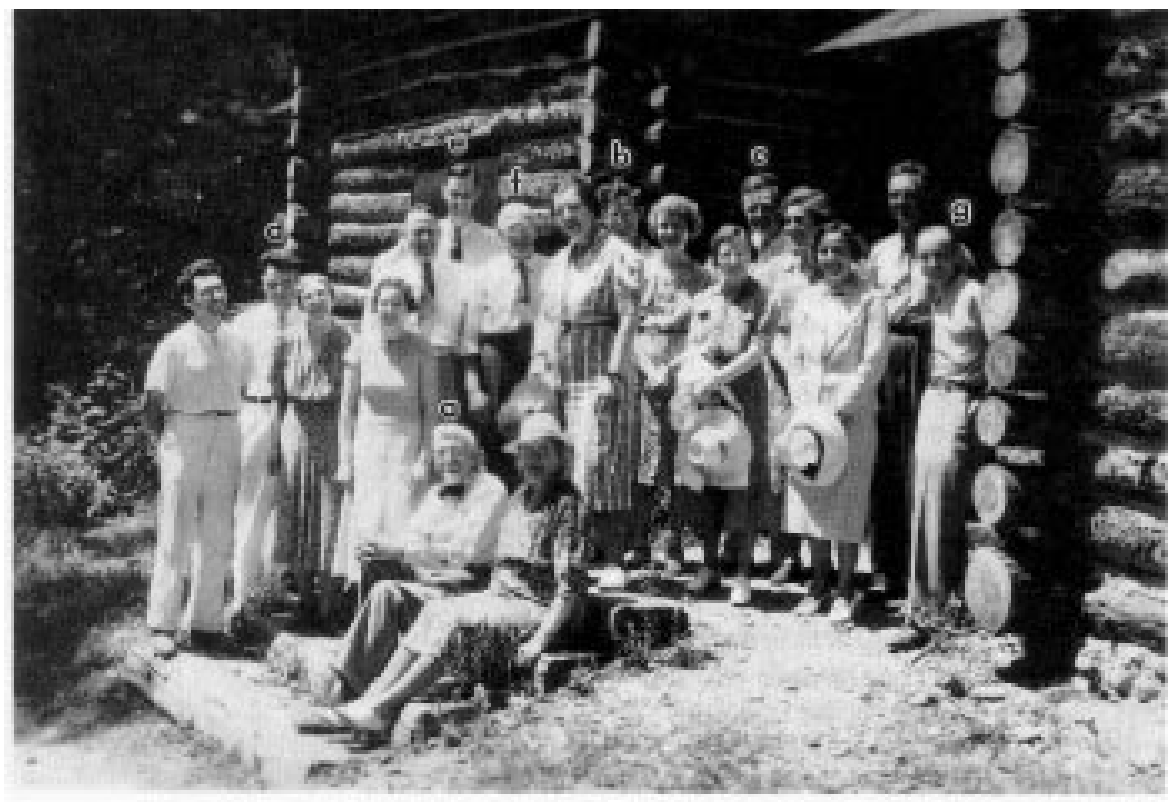

Fig. 3. Employees of the Ornamental Plant Crops and Diseases Investigations attending the retirement lunch for Furman Mulford on 12 July 1939. (a) Mulford; (b) Pyror; (c) Emsweller; (d) Bierley; (e) Chelestrom; (f) Allard; (g) Weiss. The log cabin now serves as the National Visitor's Center of the U.S. Dept. of Agriculture.

time required for lily flowering and on the appearance of the flowering plant. Stuart also developed improved propagation methods (Stuart, 1944).

Brierley also was involved in studying bulb storage (Brierley, 1941), but later concentrated on identifying virus diseases, developing methods for their detection, and determining how they were spread (Brierley and Smith, 1944). Brierley's studies demonstrated for the first time that aphids could transmit some lily viruses and that the control of these insects was crucial in controlling the spread of viruses. He collaborated with Floyd Smith to develop new chemicals for insect control (Smith et al., 1947).

McWhorter and McClellan investigated the causes of wilt diseases. They determined the environmental conditions that caused the most severe infection and spread of diseases, such as Fusarium and Botrytis. They worked closely with Stuart to develop forcing methods that reduced the occurrence of these diseases (McClellan and Stuart, 1945).

Lumsden studied the effects of postharvest conditions on flower storage. He found that the common practice of sending cut flowers in shipments of ripe fruit significantly lowered the shelf life of the flowers (Lumsden et al., 1940). The small quantity of ethylene released by the fruit was responsible.

Emsweller initiated investigations on the genetics of polyploids. He used colchicine to induce tetraploidy in lily species and hybrids (Emsweller and Brierley, 1940). Two of his goals were to 1) use polyploidy to increase the fertility of sterile interspecific hybrids; and 2) determine if polyploidy, which increased the dry weight (or substance) of flowers, could be used to produce cultivars that had a longer shelf life. Through advanced selection and breeding, three superior Easter lily cultivars with larger flowers and increased shelf life eventually were released in 1958 (Uhring, 1965). Emsweller also developed cytological methods to determine the origin of hybrids with unknown parentage (Emsweller and Burrell, 1947).

During this period, research on ornamental continued his garden chrysanthemum breeding project and released several additional cultivars. McCann developed a strain of seedpropagated, cut-flower carnations. Until this time, carnation cultivars were hybrids that did not breed true from seed. They had to be asexually propagated via cuttings. Asexual propagation led to an increased incidence of many diseases; the use of seed lines greatly reduced the disease problems in carnations. Viral and wilt diseases were transmitted through propagation to cuttings but not to seed. Traub developed new methods of inducing high frequencies of polyploidy through repetitive colchicine treatment (Traub, 1951). His physiological studies on the effect of tetraploidy in daylily (Hemerocallis L.) started a new trend in breeding this crop, which is still pursued today.

In retrospect, perhaps three accomplishments dominate the history of USDA research on ornamental plants from 1862 to 1940 . First, Mulford and others, through research and breeding, produced the first winter-hardy, summer-flowering garden chrysanthemums. Before these new cultivars, chrysanthemums flowered in late fall and winter and had to be grown in greenhouses. Second, Griffith and others developed methods for the large-scale production of bulbs and their subsequent forcing. Before these techniques, bulb-growing and forcing methods within the United States were not efficient or reliable. The third accomplants other than lilies was conducted. Mulford

\section{Conclusion}


plishment was the discovery of photoperiodism and its practical application in controlling plant development. Before a crop can become successful commercially, a thorough understanding of its photoperiodic response is needed.

We have not attempted to provide a complete history of the USDA research on ornamental research. Rather, we have highlighted individuals and a few of their research results that were important in the development and commercialization of several of our more common ornamental plants for the garden, landscape, and greenhouse.

\section{Literature Cited}

Bahrt, G.M. 1938. The 1938 amaryllis show of the Bureau of Plant Industry, USDA. Herbertia 4:90.

Brierley, P. 1941. Effect of cold storage of Easter lily bulbs on subsequent forcing. J. Agr. Res. 62:317335.

Brierley, P. and F.F. Smith. 1944. Studies on lily virus diseases. Phytopathology 34:529-555.

Corbett, L.C. 1924. Continuing Dr. van Fleet's work. Amer. Rose Ann. 8:27-28.

Emsweller, S.L. and P. Brierley. 1940. Colchicineinduced tetraploidy in Lilium. J. Hered. 31:223230.

Emsweller, S.L., P. Brierley, D.V. Lumsden, and F.L. Mulford. 1937. Improvement of flowers by breeding. 1937 U.S. Dept. Agr. Yrbk. Dept. Agr. p. 8901031.

Emsweller, S.L. and H.R. Burrell. 1947. Origin of Lilium T. A. Havemeyer. North Amer. Lily Yrbk. 1:21-26.

Ferrall, J.A. 1938. Chrysanthemums. U.S. Dept. Agr., Fruit and Vegetable Crops Div. Nwsl. 10:256-257.

Galloway, B.T. 1899. Progress of commercial growing of plants under glass. 1899 Yrbk. Dept. Agr. p. 575590.

Galloway, B.T. 1900. William Saunders. 1900 Yrbk. Dept. Agr. p. 625-630.

Galloway, B.T. 1901. Horticultural investigations. U.S Dept. Agr. 1901 Annu. Rpt. p. 142-148.

Garner, W.W. and H.A. Allard. 1920. Effect of the relative length of day and night and other factors of environment on growth and reproduction in plants. J. Agr. Res. 18:553-606.

Griffith, D. 1920. The production of lily bulbs. U.S. Dept. Agr. Circ. 102.

Griffith, D. 1922. The production of tulip bulbs. U.S. Dept. Agr. Circ. 108.

Griffith, D. 1928. The production of certain iris bulbs. U.S. Dept. Agr. Circ. 25.

Griffith, D. 1930a. Daffodils. U.S. Dept. Agr. Circ. 122

Griffith, D. 1930b. The production of hyacinth bulbs. U.S. Dept. Agr. Circ. 112

Griffith, D. 1932. Bulb investigations. U.S. Dept. Agr., Fruit and Vegetable Crops and Diseases Nwsl. 4:84-87.

Griffith, D. 1933. Some hybrid Martagon lilies. U.S. Dept. Agr. Circ. 299

Hall, R. 1863. House plants. U.S. Dept. Agr. 1863 Annu. Rpt. p. 366-381.

Ling, C.L. 1935. Increased funds for federal horticultural activities. Florists Exchange 134:13-14.

Lumsden, D.V., R.C. Wright, T.M. Whiteman, and J.W. Byrnes. 1940. Fruit and flowers should not be stored together. Florists' Rev. 86:22-23.

McClellan, W.D. and N.W. Stuart. 1945. Prevention of scale rot in propagation of Easter lily bulbs. Florists' Rev. 95:19-20.

McFarland, J.H. 1924. Story of Mary Wallace Rose. Amer. Rose Ann. 8:15-18.

Morrison, B.Y. 1953. Glendale azaleas. U.S. Dept. Agr. Monogr. 20.

Mulford, F.L. 1919. National Rose Test Garden to date. Amer. Rose Ann. 3:137-145.

Norton, J.B. 1905. Carnation seedlings and Mendel's law. Soc. Hort. Sci. Proc. 1:105.
Oliver, G.W. 1903. The propagation of Easter lily from seed. U.S. Dept. Agr., Bur. Plant Industry Bul. 39.

Parker, M.W. and H.A. Borthwick. 1940. Floral initiation as influenced by photosynthesis during the induction period. Bot. Gaz. 102:256-268.

Saunders, W. 1897. Experimental gardens and grounds. 1897 Yrbk. Dept. Agr. p. 180-204.

Smith, E.F. 1901. Wakker's hyacinth germ. U.S. Dept. Agr., Bur. Plant Industry Bul. 26.

Smith, F.F., R.A. Smith, R.A. Fulton, P.H. Lung, and P Breirly. 1947. Potent new insecticide and new method undergo trial. Florists' Rev. 99:31-35.

Spillman, W.J. 1909. Application of some of the principles of heredity to plant breeding. U.S. Dept. Agr., Bur. Plant Industry Bul. 165.

Stuart, N.W. 1943. Influence of temperature and storage period on forcing lilies. Florists' Rev. 92:13-15. Stuart, N.W. 1944. Propagating lily scales in sphag- num. Rapid and successful method. Florists' Rev. 93:21-22.

Stuart, W. 1912. Mendelian inheritance in the carnation. Vermont Agr. Expt. Sta. Bul. 163:49-72.

Traub, H.P. 1951. Colchicine-induced Hemerocallis polyploids and their breeding behavior. Plant Life 7:83-116.

Uhring, J. 1965. Beltsville lily introductions. North Amer. Lily Yrbk. 17:109-117.

van Fleet, W. 1916. Possibilities in the production of American garden roses. Amer. Rose Ann. 1:27-36.

Weiss, F. 1930. Narcissus basal rot control. Florist Nursery Exchange 123:11-12.

Woods, A.F. 1900. Stigmonose: A disease of carnations and other pinks. U.S. Dept. Agr., Bur. Plant Industry Bul. 19.

Yerkes, G.E. 1927. Rose understock trial at Arlington Farm. Amer. Rose Ann. 11:47-52. 